\title{
Sistem Informasi Terpadu untuk Pembuatan Surat Keterangan Pendamping Ijasah
}

\author{
Nur Cahyo Wibowo ${ }^{1}$, Agung Brastama Putra ${ }^{2}$, Nugroho Utomo ${ }^{3}$ \\ ${ }^{1,2}$ Sistem Informasi, UPN "Veteran” Jawa Timur \\ ${ }^{1}$ nurcahyo.si@upnjatim.ac.id \\ 2agungbp.si@upnjatim.ac.id \\ ${ }^{3}$ Teknik Sipil, UPN "Veteran" Jawa Timur \\ ${ }^{3}$ nugroho.ts@upnjatim.ac.id
}

\begin{abstract}
Abstrak- Surat Keterangan Pendamping Ijazah (SKPI) sudah diberlakukan berdasarkan Permen Dikbud Nomor 81 tahun 2014. UPN "Veteran" Jawa Timur sebagai salah satu penyelenggara pendidikan tinggi wajib untuk turut melaksanakannya. Di dalam dokumen SKPI terdapat informasi tentang capaian-capaian yang diraih mahasiswa; baik yang akademik, maupun non-akademik. Kesulitan yang dihadapi adalah bagaimana merangkum semua informasi tersebut menjadi satu dokumen meskipun bersumber dari beberapa pihak. Dalam penelitian ini akan dikembangkan sebuah sistem online berbasis web untuk menangani pembuatan SKPI secara terpadu. Teknologi pemrograman yang digunakan adalah bahasa PHP. Sedangkan untuk sistem pengelolaan basis datanya memakai DBMS MySQL. Hasil yang diharapkan dari penelitian ini adalah pembuatan SKPI bisa lebih sistematis, terpadu, dan cepat. Dengan sistem online, juga bisa menekan penggunaan kertas sebagai media cetak dokumen. Hal ini tentunya juga akan lebih ramah bagi lingkungan.
\end{abstract}

Kata Kunci- SKPI, Surat Keterangan Pendamping Ijasah, Sistem Informasi, Web.

\section{Pendahuluan}

Berdasarkan Peraturan Menteri Pendidikan dan Kebudayaan Nomor 81 Tahun 2014, perguruan tinggi wajib menyertakan Surat Keterangan Pendamping Ijazah bagi lulusannya. Dua perguruan tinggi yang telah menerapkan SKPI adalah Universitas Bina Nusantara dan Politeknik Negeri Bandung. Dalam kedua contoh SKPI yang diterbitkan oleh kedua kampus tersebut, muncul informasi tentang prestasi yang diraih dan kegiatan softskill yang diikuti mahasiswa selama kuliah. Sumber informasi dalam dokumen SKPI cukup beragam. Diantaranya informasi tentang capaian prestasi akademik dan kemahasiswaan yang berasal dari Biro Akademik, Kemahasiswaan, Perencanaan, dan Kerjasama (AKPK), Program Studi serta LP3M. Sedangkan informasi tentang keterampilan berbahasa diperoleh dari UPT Bahasa.

Sistem pembuatan SKPI yang tersebar sumber datanya ini berpotensi untuk memberikan dampak pada prosesnya yang membutuhkan waktu cukup lama dan kurang sistematis jika masih dikerjakan secara manual paper based. Program Studi, LP3M dan Biro AKPK sebagai pelaku utama dalam kompilasi SKPI ini akan sangat disibukkan dengan pengumpulan data dari mahasiswa. Kesibukan yang tinggi tersebut akan memicu terjadinya kesalahan yang disebabkan oleh manusia. Untuk mengatasi masalah di atas, dalam penelitian ini akan dibangun sebuah sistem informasi berbasis web yang memungkinkan pembuatan SKPI secara terpadu dengan melibatkan beberapa satker/ unit sekaligus. Sistem informasi pembuatan SKPI ini sangat dibutuhkan oleh lembaga dalam rangka menjalankan amanah pemerintah (Kemendikbud/ Kemenristek Dikti). Dengan jumlah wisudawan UPN "Veteran" Jawa Timur yang di kisaran 700 orang tiap semester, maka pengurusan SKPI secara manual beresiko menimbulkan masalah dalam prosesnya.

\section{Surat Keterangan Pendamping Ijazah (SKPI)}

SKPI diatur dalam Peraturan Menteri Pendidikan dan Kebudayaan nomor 81 tahun 2014 [1]. Peraturan tersebut membahas tentang Ijazah, Sertifikat Kompetensi, dan Sertifikat Profesi Pendidikan Tinggi. SKPI adalah dokumen yang memuat informasi tentang pencapaian akademik atau kualifikasi dari lulusan pendidikan tinggi bergelar. Ijazah yang diberikan kepada lulusan perguruan tinggi disertai paling sedikit disertai dengan transkrip akademik dan SKPI.

SKPI merupakan dokumen tambahan yang menyatakan kemampuan kerja, penguasaan pengetahuan, dan sikap/moral seorang lulusan yang lebih mudah dimengerti oleh pihak pengguna di dalam maupun luar negri dibandingkan dengan membaca transkrip. SKPI memberikan penjelasan yang objektif mengenai prestasi dan kompetensi pemegangnya. Dengan demikian adanya SKPI akan meningkatkan kelayakan kerja ( employability) terlepas dari kekakuan jenis dan jenjang program studi. SKPI dikeluarkan oleh institusi pendidikan tinggi yang berwenang mengeluarkan ijazah sesuai dengan peraturan perundang-undangan yang berlaku. SKPI hanya diterbitkan setelah mahasiswa dinyatakan lulus dari suatu program studi secara resmi oleh Perguruan Tinggi. SKPI yang asli diterbitkan mengunakan kertas khusus (barcode/ hallogram security paper). Untuk memudahkan klarifikasi data, maka penerima SKPI hendaknya dicantumkan dalam situs resmi Perguruan Tinggi.

Secara umum SKPI berisi data tentang profil mahasiswa dan capaiannya studinya selama di kampus. Misalnya adalah capaian sesuai Kerangka Kualifikasi Nasional Indonesia dan levelnya, serta capaian berupa prestasi di dalam kegiatan akademik maupun non akademik. SKPI ditulis dalam bahasa Indonesia dan bahasa Inggris dan ditandatangani oleh Dekan. 
Dalam hal SKPI rusak atau hilang, maka boleh diterbitkan Surat Keterangan Pengganti.

Detil informasi yang ada di dalam SKPI adalah sebagai berikut: logo dan nama PT, nomor keputusan pendirian PT, nama program studi, nama lengkap dan tempat, tanggal lahir pemilik SKPI, nomor pokok mahasiswa, tanggal bulan tahun masuk dan kelulusan, nomor seri ijasah, gelar yang diberikan dan singkatannya, jenis dan program pendidikan, capaian pembelajaran dan level KKNI, persyaratan penerimaan, bahasa pengantar kuliah, sistem penilaian, lama studi, jenis dan program pendidikan lanjutan, serta skema sistem pendidikan tinggi. Penandatanganan SKPI dilakukan oleh Dekan jika PT berbentuk Universitas/ Institut, atau oleh Pimpinan Unit Pengelola Program Studi jika PT berbentuk Sekolah Tinggi, atau oleh Direktur jika PT berbentuk Akademi Komunitas.

\section{Beberapa Cara Pembuatan SKPI}

Berdasar kajian awal yang dilakukan, beberapa kampus sudah mengawali pembuatan SKPI secara online berbasis teknologi informasi/ internet, meskipun ada juga yang masih memakai formulir cetak manual. Ada dua pilihan pendekatan online yang sudah dilakukan, yaitu kampus mengunggah file formulir pengisian di situs universitas dan kampus menyediakan formulir isian secara online di internet. Cara yang pertama mewajibkan mahasiswa mengunduh terlebih dulu file kemudian mencetak dan mengisinya secara manual. Kemudian formulir dikumpulkan ke kampus. Sedangkan cara kedua lebih efisien. Mahasiswa hanya perlu mengisikan data yang dibutuhkan secara online tanpa harus mencetak formulir. Data akan langsung diproses oleh kampus.

Berikut ini adalah beberapa cara/ prosedur pembuatan SKPI yang diterapkan oleh universitas baik negeri maupun swasta:

\section{1) Universitas Islam Negeri Jakarta}

Pada akhir Agustus 2016, Rektor menyepakati bahwa SKPI diberlakukan mulai semester Ganjil 2016/ 2017. Isian data prestasi/ kegiatan untuk SKPI ditulis dalam lembar cetak dengan syarat lima kriteria:

1. Dilakukan selama masih berstatus mahasiswa.

2. Ruang lingkup minimal tingkat universitas.

3. Dikoordinasi, atau diakui oleh universitas.

4. Sertifikat dikeluarkan oleh lembaga yang tersertifikasi.

5. Telah diverifikasi oleh pejabat/ petugas terkait. Usai dilengkapi, mahasiswa memasukkan dokumen SKPI ke dalam program AIS. Kemudian dosen PA memverifikasi kelayakan dokumen SKPI sebelum mahasiswa menyerahkan dokumen persyaratan ujian skripsi atau uji kompetensi profesi. Terakhir, prodi memvalidasi kelayakan dokumen SKPI bersamaan pendaftaran ujian skripsi dan uji kompetensi [2].

2) Asosiasi Institusi Pendidikan Vokasi Keperawatan Indonesia Reg. 6 Jawa Timur

Pembuatan SKPI sudah menggunakan aplikasi Microsoft Excel yang dirancang sedemikian rupa sehingga mudah digunakan. Aplikasi tersebut tidak membutuhkan spesifikasi perangkat keras yang tinggi, dan tidak perlu melakukan instalasi perangkat lunak tambahan. Petugas cukup mengetikkan data-data yang dibutuhkan oleh SKPI ke dalam sheet yang telah disediakan. Termasuk di dalamnya isian data PT dan program studi, capaian pembelajaran, serta daftar mahasiswa pemegang SKPI dan prestasi-prestasinya. Aplikasi tersebut juga menyediakan fitur untuk cetak dokumen [3].

\section{3) Fakultas Sains dan Matematika Universitas Diponegoro}

Pembuatan SKPI dimulai dengan pengisian formulir yang telah disediakan pihak dekanat. File formulir yang kosong isiannya diunggah ke halaman resmi web fakultas. Mahasiswa bisa mengunduh file tersebut, kemudian mengisinya. Formulir SKPI dibedakan antara jurusan satu dengan jurusan yang lainnya. Masing-masing jurusan diberikan link yang terpisah untuk mengunduh file SKPI. Dalam gambar tersebut juga disediakan file formulir untuk validasi data SKPI. File validasi tersebut perlu dicetak dan kemudian ditandatangani oleh petugas terkait saat pembuatan SKPI [4].

\section{4) Universitas Mercubuana}

Pihak pengelola PT telah mengintegrasikan pengisian datadata SKPI dengan situs sistem informasi akademik mahasiswa. Menu pengisian SKPI menjadi salah satu menu yang disediakan oleh bidang akademik universitas. Dokumen SKPI dijadikan syarat untuk mengikuti ujian Tugas Akhir. Mahasiswa cukup mengisikan data SKPI melalui website tersebut. Data yang dimasukkan meliputi:
a. Kategori kegiatan/ prestasi
b. Tahun pencapaian
c. Nama perusahaan
d. Posisi/ jenis pengalaman

Karena hanya satu halaman pengisian untuk beberapa macam kegiatan/ prestasi, maka sepintas nama label dan isinya ada yang kurang pas. Verifikasi data SKPI dilakukan oleh bagian Tata Usaha setelah mendapatkan kopi bukti dokumen terkait dari mahasiswa [5].

\section{5) Universitas Negeri Padang}

Untuk mengurus SKPI, mahasiswa masuk ke situs sipresma.unp.ac.id guna mengunggah data prestasi dan scan dokumen bukti prestasinya sesuai dengan ketentuan yang ada. Setelah mengunggah data prestasi dan scan dokumen bukti prestasi, mahasiswa diharuskan membawa dokumen bukti prestasi yang asli ke validator sipresma di fakultas masing-masing untuk divalidasi. Apabila prestasi mahasiswa disetujui oleh validator, maka prestasi tersebut akan ditampilkan/dicetak di SKPI yang akan diterima mahasiswa pada saat wisuda [6].

\section{6) Universitas Brawijaya}

Pihak kampus telah mengunggah template dokumen SKPI ke halaman resmi situs PT. Mahasiswa mengunduh file tersebut untuk kemudian mengisikan data pada bagian aktivitas, prestasi dan penghargaan [7], [8]. 


\section{METODE}

Saat ini ada dua pilihan cara pengumpulan data untuk SKPI, yaitu pertama, mahasiswa mengunduh file formulir untuk kemudian dicetak, diisi dan dikumpulkan lagi secara manual ke kampus. Cara yang lainnya adalah dengan melakukan pengisian data secara online. Pihak kampus menyediakan formulir yang bisa diakses oleh mahasiswa melalui internet. Sedangkan di dalam sistem informasi terpadu untuk pembuatan dokumen SKPI. Disebut terpadu karena melibatkan semua satuan kerja/ unit yang menjadi sumber data bagi dokumen SKPI. Satuan kerja atau unit itu antara lain Biro Kemahasiswaan, Biro Akademik, P3AI dan Program Studi. Mahasiswa otomatis sebagai pelaku pertama/ inisiator dalam sistem ini nantinya. Sistem informasi yang akan dihasilkan nanti, dibangun secara modular/ sub sistem. Modul ini disesuaikan dengan aktor/ pelaku utama dalam sistem. Penjelasan lebih detilnya seperti dalam tabel berikut ini.

Secara umum metode penelitian yang digunakan dalam penelitian ini adalah metode pembuatan perangkat lunak, yaitu Software Development Life Cycle (SDLC). Dalam metode ini sebuah perangkat lunak dibangun mulai dari tahap pengumpulan kebutuhan, analisis dan perancangan, implementasi, uji coba dan pemeliharaan. Lebih detilnya bisa dilihat dalam Tabel I berikut ini.

\section{A. Rancangan Basis Data}

Terdapat 7 (tujuh) buah tabel utama untuk menyusun basis datanya, yaitu: Tabel Mahasiswa, Tabel Pelatihan, Tabel Akademik, Tabel Kemampuan, Tabel Prestasi, Tabel Ormawa, dan Tabel Verifikator. Tabel-tabel tersebut dirancang saling berkaitan menjadi model relasi entitas (ERD). Dua entitas pelaku/ aktor dalam sistem ini adalah mahasiswa dan petugas/ pejabat verifikator. Mahasiswa berperan mengunggah dan mengisi data beserta dokumen pendukung SKPI, sedangkan verifikator bertugas memastikan/ memvalidasi isian tersebut.
Verifikator disini adalah subsistem akademik universitas yang terlibat dalam pembuatan SKPI. Diantaranya adalah Program Studi, Bagian Akademik, Bagian Kermawa Biro AKPK, UPT Bahasa, dan LP3M. Setiap isian data yang dilakukan oleh mahasiswa akan disimpan ke dalam tabel yang sesuai. NPM mahasiswa dan ID verifikator akan menjadi atribut kunci di dalam setiap tabel isian data SKPI. Hal ini sebagai pembeda antara isian satu dengan yang lainnya. Tercatatnya ID verifikator ke dalam tabel-tabel isian SKPI juga menandakan bahwa isian tersebut sudah diverifikasi. Jika semua isian sudah terverifikasi semua, maka dokumen SKPI baru bisa dicetak oleh mahasiswa.

\section{HASIL}

Setelah rancangan basis data diimplementasikan ke dalam DBMS MySQL, maka dilanjutkan dengan pembuatan sistem informasinya. Source code sistem informasi ditulis dalam bahasa pemrograman web PHP. Berikut ini adalah tampilan beberapa halaman utamanya:

- Halaman Mahasiswa

Seperti yang terlihat pada Gbr. 1 di bawah ini, setiap mahasiswa bisa mengisikan data diri dan data capaian masing-masing. Termasuk juga mengunggah file dokumen pendukungnya ke sistem.

- Halaman bagian Akademik Biro AKPK

User admik bisa melakukan verifikasi data-data akademik mahasiswa, dan melakukan pencetakan SKPI. Tampilannya seperti yang terlihat pada Gbr. 2 .

- Halaman Program Studi

Sedangkan user Program Studi bisa melakukan verifikasi data prestasi dan kesertaan organisasi mahasiswa melalui halaman yang terlihat pada Gbr. 3 .

- Contoh Hasil Cetak SKPI

Gbr. 4 adalah potongan contoh hasil dokumen SKPI yang siap untuk dicetak oleh petugas di bagian Akademik.

TABEL I

MODUL DAN PROSES UTAMA SISTEM SKPI

\begin{tabular}{|c|c|}
\hline Modul & Proses Utama \\
\hline Mahasiswa & $\begin{array}{l}\text { 7) Mengisi/ memverifikasi biodata. } \\
\text { 8) Mengisi judul skripsi. } \\
\text { 9) Mengisi prestasi akademik dan non akademik. } \\
\text { 10)Mengunggah dokumen penunjang. }\end{array}$ \\
\hline LP3M & - Mengisi kesertaan kegiatan outbond bela negara. \\
\hline UPT Bahasa & $\begin{array}{l}\text { - Mengisi capaian skor TOEFL mahasiswa. } \\
\text { - Menulis/ mengubah/ memverifikasi isian teks berbahasa Inggris. }\end{array}$ \\
\hline $\begin{array}{lll}\text { Bagian } & \text { Akademik } & \text { Biro } \\
\text { AKPK } & & \\
\end{array}$ & - Mengisi data akademik mahasiswa (IPK, lama studi, sistem nilai). \\
\hline $\begin{array}{l}\text { Bagian Kemahasiswaan } \\
\text { Biro AKPK }\end{array}$ & - Memverifikasi capaian prestasi kemahasiswaan di tingkatan universitas ke atas. \\
\hline Program Studi & $\begin{array}{l}\text { - Mengisi profil program studi. } \\
\text { - Memverifikasi judul skripsi mahasiswa. } \\
\text { - Memverifikasi capaian prestasi mahasiswa dalam bidang akademik maupun non- } \\
\text { - } \text { akademik di tingkatan program studi. } \\
\text { - Mengisi/ mengubah capaian KKNI dan tingkatannya. }\end{array}$ \\
\hline
\end{tabular}




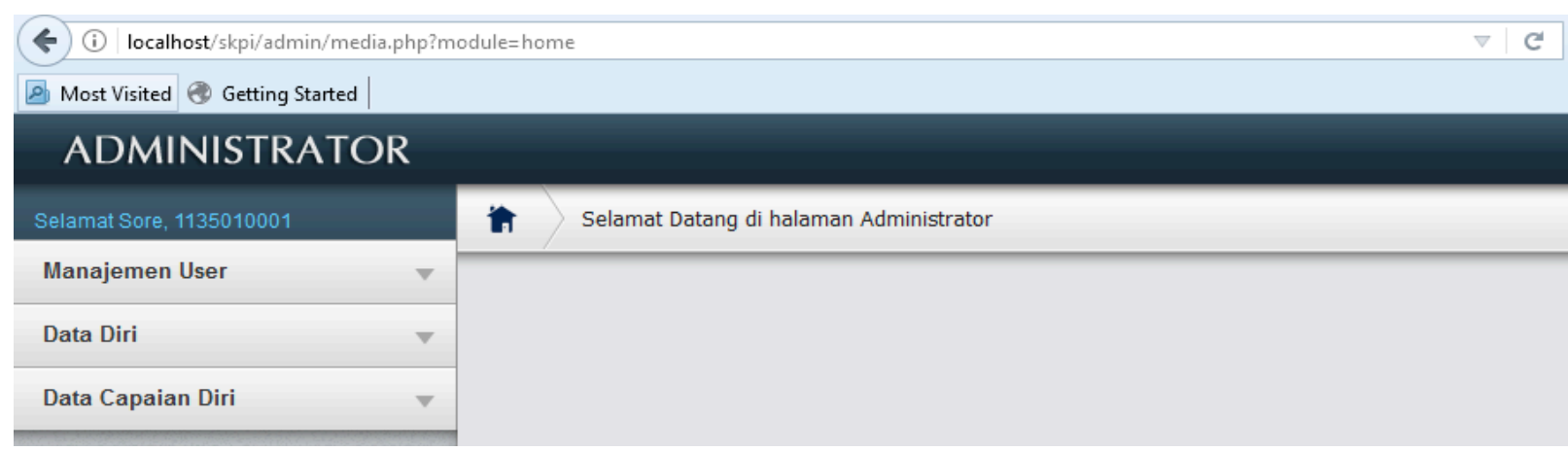

Gbr 1. Tampilan halaman Mahasiswa.

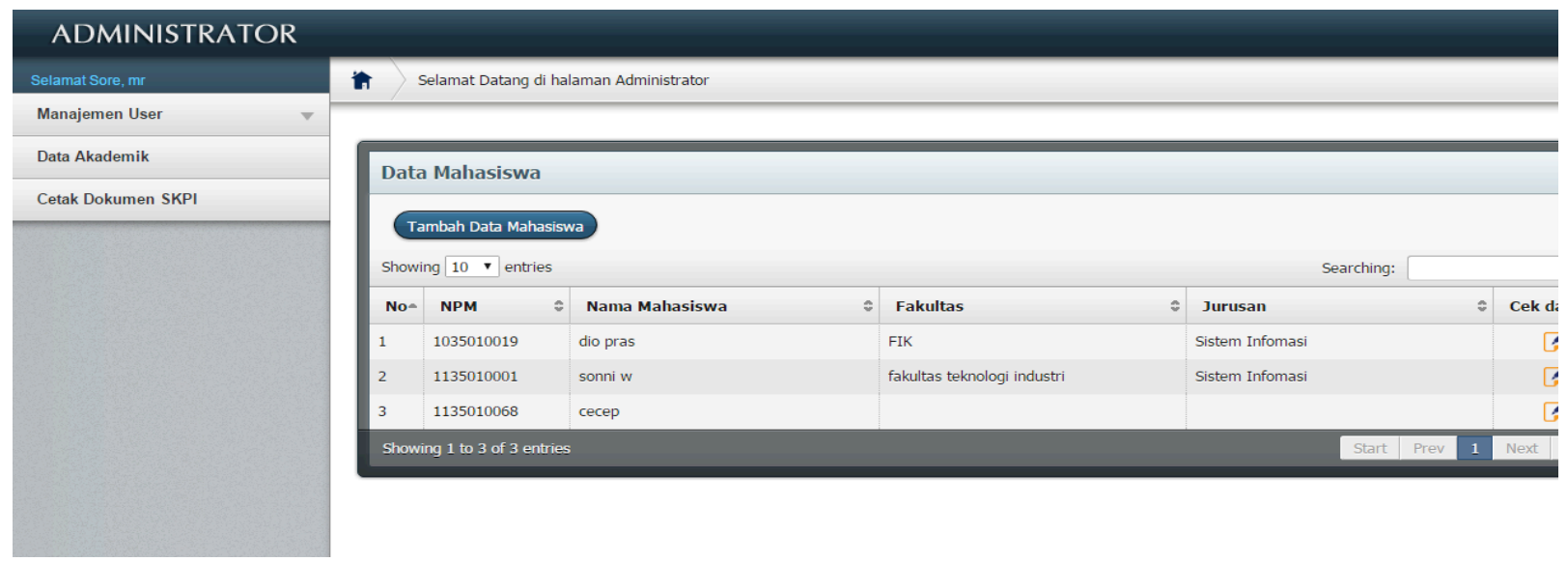

Gbr 2. Tampilan halaman Bagian Akademik Biro AKPK.

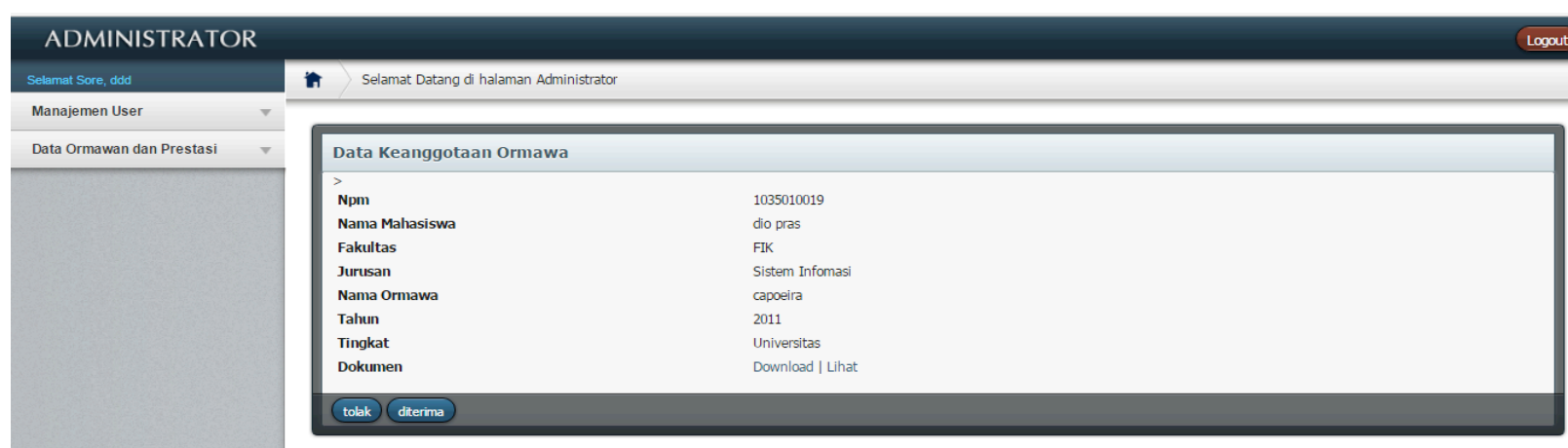

Gbr 3. Tampilan halaman Program Studi.

\begin{tabular}{|c|c|}
\hline $\begin{array}{r}\text { SURAT KE } \\
D \\
D \\
\text { Nomot }\end{array}$ & $\begin{array}{l}\text { ENDANIPING IJAZAH } \\
\text { PLEMENT } \\
\text { la1/BNN00324 }\end{array}$ \\
\hline \multicolumn{2}{|c|}{$\begin{array}{l}\text { Surat Keterangan Pendamping Ijazah ini sebagai pelengkapp ijazah yang menerangkan capaian } \\
\text { pembelajaran dan prestasi dari pemegang ijazah selama masa studi }\end{array}$} \\
\hline \multicolumn{2}{|c|}{ 1. INFORMASI TENTANG IDENTITAS DIRI PEMEGANG SKPI } \\
\hline 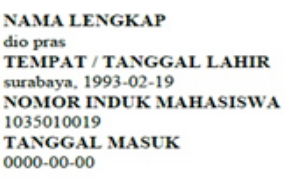 & $\begin{array}{l}\text { TANGGAL LULUS } \\
\text { 2017-01-31 } \\
\text { NOMOR IJAZAH } \\
\text { 123 } \\
\text { GELAR } \\
\text { sarjana komputer(S.kom) }\end{array}$ \\
\hline 2. INFORMASI TENTANG IDE & ELENGGARAAN PROGRAM \\
\hline
\end{tabular}

Gbr 4. Contoh tampilan hasil dokumen SKPI. 


\section{KESIMPULAN}

Dengan adanya sistem informasi terpadu ini akan memungkinkan pengurusan dan pembuatan dokumen SKPI yang lebih cepat. Selain itu juga akan lebih hemat dalam sumber daya, baik itu yang berupa tenaga manusia (mahasiswa, pegawai), maupun yang berupa bahan habis pakai (kertas, map). Karena, dengan sistem ini, pembuatan SKPI tidak perlu lagi ada pergerakan orang dari satu tempat ke tempat yang lainnya dengan membawa dokumen-dokumen terkait. Sedangkan untuk perbaikan ke depan kiranya (a) perlu menambahkan fitur perbaruan uraian capaian pembelajaran dan profilnya pengguna program studi, (b) menyempurnakan fitur notifikasi bagi semua pengguna terkait, sehingga jika ada informasi yang update bisa lebih cepat diketahui dan diproses.

\section{UCAPAN TERIMA KASIH}

Terima kasih disampaikan kepada segenap jajaran pimpinan di fakultas dan universitas yang telah mendukung terselenggaranya Seminar Nasional SANTIKA 2020.

\section{REFERENSI}

[1] Menteri Pendidikan dan Kebudayaan. 2014. Peraturan Menteri Nomor 81 Tahun 2014 tentang Ijazah, Sertifikat Kompetensi, dan Sertifikat Profesi Pendidikan Tinggi. Kementerian Pendidikan dan Kebudayaan.

[2] UIN Syarif Hidayatullah. 2016. SKPI UIN Jakarta Tahun Ini Dimulai. URL: http://www.uinjkt.ac.id/id/skpi-uin-jakarta-tahun-inidimulai/. Diakses 15 September 2016.

[3] Tamsuri, Anas. 2014. Manual Penggunaan: Aplikasi Penyusunan SKPI Pendidikan Vokasi Keperawatan. AIPViKI Regional 6 Jawa Timur.

[4] Universitas Diponegoro. 2015. Surat Keterangan Pendamping Ijasah. Fakultas MIPA.

[5] Universitas Mercubuana. 2014. Alur Proses Pengisian Pengalaman Mahasiswa.

[6] Universitas Negeri Padang. 2013. Panduan Sipresma.

[7] Universitas Brawijaya. 2015. Surat Keterangan Pendamping Ijasah. Fakultas Ilmu Komputer.

[8] Universitas Brawijaya. 2015. Surat Keterangan Pendamping Ijasah. Fakultas MIPA 